\title{
Reasonability of Using LMS Moodle Tests as a Form of Control in Teaching a Foreign Language for Students of Secondary Vocational Education
}

\author{
Svetlana Kapsargina \\ Krasnoyarsk State Agrarian University \\ Krasnoyarsk, Russia \\ kpsv@bk.ru
}

\author{
Julia Olentsova \\ Krasnoyarsk State Agrarian University \\ Krasnoyarsk, Russia \\ tutor.eng@yandex.ru
}

\begin{abstract}
One of the most important places in determining the strategic goal of teaching in the system of secondary vocational education is the social order of state with regard to the younger generation. Discipline "Foreign language" is a mandatory part of the general humanitarian and socio-economic educational cycle included in the training program of middlelevel specialists. One of the important tasks in the training of such specialists can be considered the development of foreign language communicative competence for successful implementation in professional activities. Control is the most important condition for effective management in the process of teaching a foreign language and an effective form of feedback for the students of secondary vocational education.

Modern computer technologies allow providing constant control of students' activity in the process of foreign language teaching. We use LMS Moodle for the organization and control of foreign language teaching. Using LMS Moodle tests as a form of control in teaching a foreign language for students of secondary vocational education is designed to establish the degree of students' realization of the tasks assigned to them in the learning process, to identify the formed level of professional and foreign language communicative competence.

Reasonability of using LMS Moodle tests as a form of control in teaching a foreign language for students of secondary vocational education can be distinguished in the following ways: the teacher can check objectively the knowledge of a large number of students with minimal time; immediate calculation of test results; formation of a sufficiently large number of test option.
\end{abstract}

Keywords: LMS Moodle tests, control, foreign language, secondary vocational education, students

\section{INTRODUCTION}

Innovative approaches to the organization and conduct of classes in a foreign language are based on the use of information and communication technologies, involving the restructuring of the content and organizational and methodological forms of education, the development of modern means in information technology support and development of the educational process $[1,2]$. One of the most important elements of the educational process is the control of students' knowledge, which monitors effectively the dynamics of learning material, assesses the level of knowledge, skills and abilities of students and helps to make the necessary adjustments to the organization of educational activities. For any education system, quality control of students' knowledge is one of the priorities. At present, the solution of such a problem is a necessary condition for the educational process, as "pedagogical tests open promising directions for improving the training quality by the system development of monitoring the training results in the conditions of cooperation between the teacher and the student" [3]. The problem of the methods choice for knowledge quality control is considered relevant in the implementation of the educational program standards. In this regard, the question of how to determine objectively and accurately this quality is raised. It is necessary that the control system is universal and is based not only on the identification of knowledge, skills, future professionals, but also to identify their creative abilities and other personality traits.

Teachers of a foreign language are faced with complex tasks: how to make the process of mastering language material accessible, as well as quickly and control effectively the acquired knowledge. The student's training quality is checked by the assimilation degree of the required training material in accordance with certain topics and sections of the curriculum. In this case, the teacher is offered an effective tool for monitoring learning outcomes, such as testing [4].

Correctly organized control of knowledge, skills and abilities implements both verification and training functions. The control data is not only the results and evaluation of educational activities in general, but also serves as a form of repetition and consolidation, improvement of previously acquired knowledge. In addition, the control of knowledge performs developmental and educational functions, when as a result of the test; the student trains memory, attention, thinking 
and imagination, learns to reproduce the learned, systematizes and summarizes the available knowledge.

The control in educational activity means a certain system of its functioning efficiency check; it has to correspond to the following principles: 1) to have individual character (control of each student's work); 2) to be systematic, regular; 3) to have various forms; 4) to be comprehensive; 5) to be objective; 6) to have the differentiated approach; 7) to assume unity of requirements $[5,6]$.

It should be noted that a special place is occupied by the works of R. P. Milrud, A. A. Mirolyubova, I. A. Rapoport, which are devoted to the study of testing issues and problems in teaching foreign languages.

Electronic testing has replaced traditional forms of control, which corresponds to the modern concept of modernization and informatization of the Russian educational system. The use of foreign language testing has more advantages compared to other control types of students' mastering in language material at different levels of education. As an integral part of the class, it provides an opportunity for the student to work in the mode he needs, gradually moving from one level of knowledge accumulation to another. Test exercises allow monitoring the work of each student. When using language tests, the conclusion is made about which lexical and grammar material will be better assimilated, which in turn provides an opportunity for the teacher to plan and adjust the learning process in accordance with the result of the passed tests and focus on the insufficiently studied material. Thus, it allows applying a differentiated approach in training. The absence of labor-intensive verification of written works makes it possible to conduct testing more often, that is, to be systematic and regular. The testing efficiency allows covering a larger number of students with minimal time compared to the written control work and the time allotted for its verification. Testing allows the students to create a sense of knowledge constant control and thereby activate their independent work during preparation for the test and motivate their work in each class. Testing has multi-functionality and provides an opportunity to test comprehensively the knowledge of the students on the passed language material, to form speech skills, to analyze the characteristic mistakes and the reasons for their occurrence [7,8].

According to recent studies, there is a tendency among young people in Russia to receive secondary vocational education (SVE). One of the urgent tasks is to train middlelevel specialists at a sufficiently high level, ready to solve professional problems and be responsible for their implementation. With this aim, content of secondary vocational education in various specialties was updated to increase the level of SVE graduates, providing intellectual and humanitarian development of personality. The state educational standard of secondary vocational education, which determines the state requirements for the content and level of graduates' training, was developed and put into effect.

Discipline "Foreign language" is a mandatory part of the general humanitarian and socio-economic educational cycle included in the training program of middle-level specialists. According to the requirements of the federal state educational standard (FSES) of secondary vocational education, graduates must be able to communicate (orally and in writing) in a foreign language on every day and professional topics. Training speech competence (speaking, listening, reading, writing), involves the formation of language competence mastery of language means (phonetic, spelling, lexical, grammatical).

In Krasnoyarsk State Agrarian University faculty members of the Foreign Language Department are developing actively electronic training courses for SVE students, as well as introducing electronic testing on electronic platform LMS Moodle (full name - Modular Object-Oriented Dynamic Learning Environment)[9-13].

The main tools used in LMS Moodle for monitoring students' knowledge of a foreign language include "Quiz", "Task", "Forum" and "Chat".

Some variants of test exercises created with the help of the "Quiz" tool and suitable for the discipline "Foreign language" are offered: 1) true/false; 2) select missing words; 3) short answer; 4) multiple choice; 5) drag and drop into text, 6) embedded answers (cloze) questions. Students do test exercises, after which the system automatically gives the result.

\section{METHODS AND RESULTS}

We consider the skills and abilities that are tested using this tool "Quiz" in LMS Moodle at the example of the discipline "Foreign language" for students of secondary vocational education, the direction 35.02.08 «Electrification of agriculture».

\section{A. Listening comprehension skills}

To do this, the creators of the course decided to add audio text to the main text. Modern computer technology allows converting any original text into an audio file. Therefore, the audio equipment with visual support helps students in the initial acquaintance with the content of the new text. For control this skill such tool of "Quiz" can be effectively use, as "Embedded answers (Cloze) questions". Questions of this type are very flexible and consist of a passage of text that has various answers embedded within it, including short answers, numerical answers and multiple choice. After reading the proposed audio files, students do various exercises, for example, drop the proposed words in the text, insert the missing words and phrases in the text, and choose the right variant. The questions relate directly to the information contained in the audio file, as the teacher should check the students' understanding of the audio material listened. When checking, the teacher can write comments, that is, to carry out feedback $[14,15]$.

As an example, we can present such exercises for listening comprehension (Fig. 1).

Task 1: Listen to the text and choose the right variant.

Students should listen to the text and choose the right variant of the word expressions. 
Students should choose the right translation of the word.

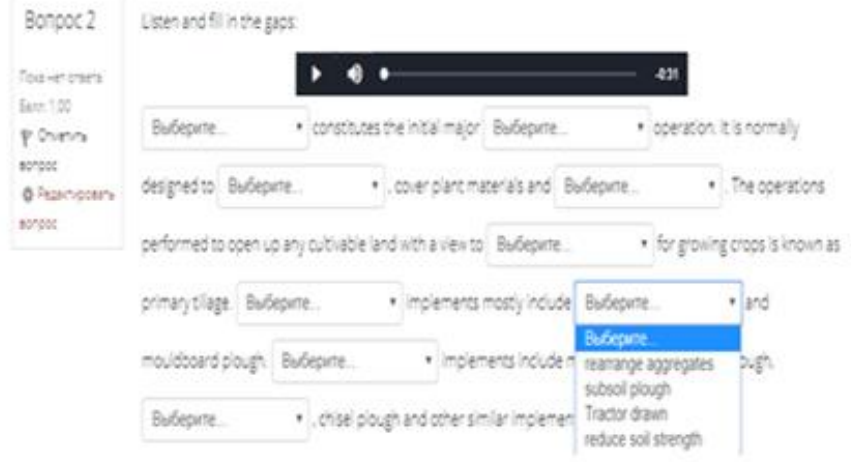

Fig. 1. An example of a listening comprehension exercise

\section{B. Grammar skills}

It is also more expedient to control the students' knowledge of grammar material by tests. Most often, "Multiple choice questions" are used to test grammar knowledge, in which students need to choose the correct answer from several proposed variants [16].

As an example, we can present such exercises for grammar skills (Fig. 2).

1. This desert is ... the one you made last night.

\section{sweetest \\ sweeter than \\ more sweeter than \\ sweet as}

Fig. 2. An example of a grammar exercise

In comparison with usual paper grammar tests, such electronic testing with LMS Moodle has the following advantages: 1) there is an opportunity to work distantly and, as a consequence, to save time; 2) machine testing provides objectivity of evaluation and saves time of the teacher.

\section{Vocabulary skills}

For control this skill such tool of "Quiz" can be effectively use as "Select missing words". In LMS Moodle, there is a drop zone with a list of possible meanings after the word, from which the student need to choose the correct translation.

As an example, we can present such exercises for vocabulary skills (Fig. 3).

Task 1. Choose the right translation of the word.

\begin{tabular}{|c|c|c|}
\hline Bonpoc 7 & engine - & Выберите... \\
\hline Пока нет ответа & & Выберите... \\
\hline $\begin{array}{l}\text { Балл: } 1,00 \\
\text { P Отметить } \\
\text { вопрос }\end{array}$ & & $\begin{array}{l}\text { двигатель } \\
\text { скорость } \\
\text { транспортное средство } \\
\text { прицеп, тягач }\end{array}$ \\
\hline
\end{tabular}

Fig. 3. An example of a vocabulary exercise

\section{Reading skills}

The "Quiz" tool is also used successfully on LMS Moodle as a test of reading skills. We have done exercises for reading on the basis of reference sentences with the help of such element of LMS Moodle as "Drag and drop into text".

As an example, we can present such exercises for reading skills (Fig. 4).

Task 1.Put the sentences in the correct order.

Students should arrange the following sentences of text in a logical sequence.

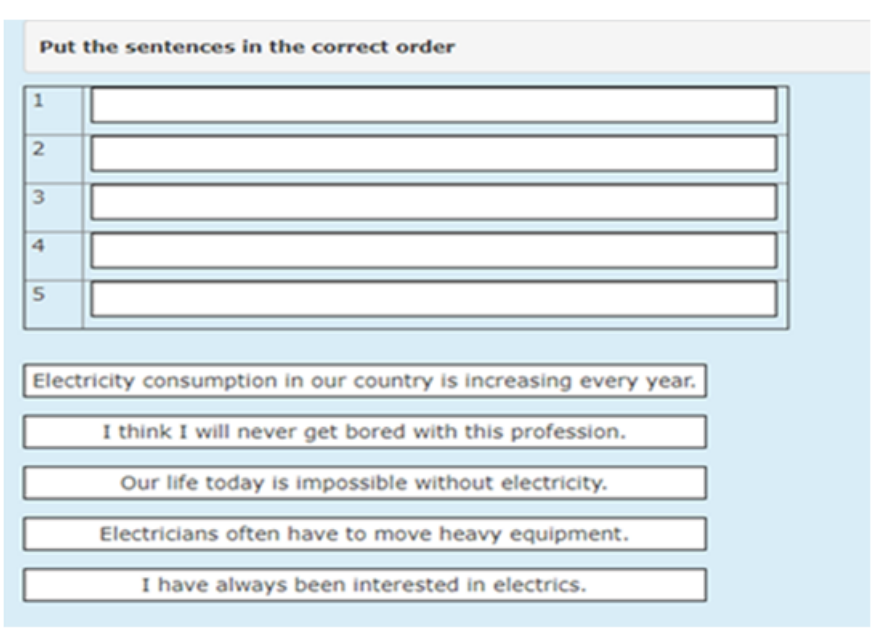

Fig. 4. An example of a reading exercise

\section{DISCUSSION}

The specificity in the use of LMS Moodle tests as a form of control when teaching a foreign language to students of secondary vocational education is as follows:

1. The test is conducted in equal conditions for all subjects: students' work with the same volume and complexity of the material at a convenient time for them.

2. The test is characterized by a quantitative expression of the task quality, which allows easily and accurately determining the correctness or inaccuracy of actions. In addition, such qualities of tests allow providing objectivity of check, independence of a results assessment from personal judgments of the checking. 
activities and work of students in the framework of the discipline [19].

Thus, the control of SVE students' knowledge in the discipline "Foreign language" by using electronic testing in LMS Moodle monitors efficiently the dynamics of learning, evaluates the level of knowledge, abilities and skills of students and helps to make necessary adjustments to training activities.

\section{REFERENCES} section of the discipline, analyze the quality of test tasks and the percentage of students who have coped with each of them.

\section{CONCLUSIONS}

Summing up, we note the reasonability of using LMS Moodle tests as a form of control when teaching a foreign language to students of secondary vocational education [17, 18]. This form of the control process organization makes it more objective, effective and has a number of advantages over traditional methods of control:

- Tests contain tasks to check both theoretical and practical material, which allows diagnosing the assimilation level of the studied material, as well as to assess the effectiveness of forms and methods of training, to carry out, if necessary, the correction of further pedagogical activity.

- The ability to place tests online allows getting an assessment immediately after the completion of the test, which is an effective means to quick check the current level of material assimilation, both the teacher and the students themselves.

- Online version of the gradebook setup allows each student to see their progress in learning the course. At the same time, access is easy to organize in such a way that the student sees only his grades and does not know about the grades of fellow students.

- The organization of electronic testing in LMS Moodle causes more interest among SVE students in comparison with traditional forms of testing organization that increases motivation to studying of a discipline "Foreign language" which is not profiling;

- Electronic testing has become an effective method of organizing independent work of students, which is an important and integral part in the process of teaching a foreign language in a limited number of classroom hours on the discipline "Foreign language";

- Final testing allows students to test their knowledge at the end of the study of each topic, and for a teacher to check the level of the material assimilation;

- The organization of regular training and final testing, analysis of its results provide the teacher with the opportunity to assess the level of the teaching material development and adjust timely the trajectory of further
[1] Shmeleva Zh. N., Antonova N. V. Control as a mandatory component of ensuring the quality of education in English classes in a non-linguistic university / / Pedagogy. Current trends in science and education. Krakow, 30-31 January 2016 p. 100-104

[2] Shmeleva Zh. N., Antonova N. V. Control as a mandatory component of ensuring the quality of education in English classes in a non-linguistic university / / Pedagogy. Current trends in science and education. Krakow, 30-31 January 2016 p. 100-104

[3] Khramtsova T. G. The main techniques in teaching foreign languages / T. G. Khramtsova // Problems of modern agricultural science: materials of the international correspondence scientific conference - Krasnoyarsk: Krasnoyarsk state agrarian university. - 2017. - p. 265-267.

[4] Vonog V. A., Alekseeva A. B., Zhavner T. V., Ponomareva E. A Possibilities of electronic training courses for educational activity control of students in the process of teaching a foreign language. Vestnik KSPU V. P. Astafiev. 2016. No. 2 (36).

[5] Levandrovskaya N. V., Khamula A. L. Electronic testing as a control form of knowledge and language learning in a military high school // (74). URL: https://cyberleninka.ru/article/n/elektronnoe-testirovaniekak-forma-kontrolya-znaniy-i-obucheniya-inostrannomu-yazyku-vvoennom-vuze (accessed 20.11.2019).

[6] Morozova Yu. V. The use of LMS Moodle to control the quality of students' knowledge in the process of teaching a foreign language. 2019 No. 3 (28). URL: https://cyberleninka.ru/article/n/ispolzovanieelektronnogo-obuchayuschego-kursa-moodle-dlya-kontrolya-kachestvaznaniy-studentov-v-protsesse-obucheniya-inostrannomu (accessed 20.11.2019).

[7] Slastenin V. A. Pedagogy: studies. manual for students. no. PED. studies'. no. Moscow: Akademiya, 2002. 576 teaching a foreign language in a non-linguistic high school // Bulletin of KamchatSTU. 2011. No. 18. URL: https://cyberleninka.ru/article/n/testkak-soderzhatelnyy-komponent-professionalno-orientirovannogoobucheniya-inostrannomu-yazyku-v-neyazykovom-vuze (accessed 22.11.2019).

[9] Kapsargina, S.A., Olentsova, Ya.A. (2019) Using the elements of gamification on LMS MOODLE in the discipline of foreign language in a non-linguistic university. The Baltic Humanitarian Journal. 1 (26). 237-241. (2019). URL: https://cyberleninka.ru/article/n/using-theelements-of-gamification-on-lms-moodle-in-the-discipline-of-foreignlanguage-in-a-non-linguistic-university (accessed 27.11.2019).

[10] Shmeleva, Zh. N., Kapsargina, S.A. (2019) The use of modern software on the Moodle platform in teaching listening and speaking in a foreign language at the non-linguistic university. Azimuth of Research: Pedagogy and Psychology. 1 (26). 147-150. (2019). URL: https://cyberleninka.ru/article/n/the-use-of-modern-software-on-lmsmoodle-in-teaching-listening-and-speaking-in-a-foreign-language-atthe-non-linguistic-university (accessed 27.11.2019).

[11] Mineeva O. A., Klopova Yu. V., Borshchevskaya Yu. M. Organization and conduct of current control in teaching a foreign language with the help of LMS MOODLE // Philological Sciences. Questions of theory and practice. Tambov. - p. 210-212

[12] Kapsargina, S.A.: (2018) The use of LMS Moodle to intensify the independent work of students in teaching a foreign language in a nonPhilological Sciences. Questions of theory and practice. 2017. No. 8-2

[8] Popova I. D. Test as a meaningful component of professionally oriented 
[16] Khramtsova T.G., Olentsova J.A. The use of quiz in LMS MOODLE as an integral part in teaching foreign languages / Topical areas of fundamental and applied research XVIII, North Charleston, USA, 2019

(25) 120-123 (2018).URL. lms-moodle-to-intensify-the-independent-work-of-students-in-teachinga-foreign-language-in-a-non-linguistic-university (accessed 27.11.2019).

[13] Khudolei N. V., Olentsova J. A. New use of MOODLE tools for distance English language learning (experience of Krasnoyarsk State Agrarian University) / 18th International Multidisciplinary Scientific GeoConference SGEM 2018, www.sgem.org, SGEM2018 Conference Proceedings, ISBN 78-619-7408-49-2 / ISSN 1314-2704, 2 July - 8 July, 2018, Vol. 18, Issue 5.4, 225-232 pp.

[14] Kapsargina S.A., Shmeleva Zh. N., Olentsova J. A. The use of LMS MOODLE in the implementation of point-rating system of evaluation in the discipline "Foreign language" / 19th International Multidisciplinary Scientific GeoConference SGEM 2019, www.sgem.org, SGEM 2019 Conference Proceedings, 2019, 225-232 pp.

[15] Golenova I. A., Markovich V. L. The use of LMS Moodle for the organization and control when teaching students the basics of medical statistics / / Achievements of fundamental, clinical medicine and pharmacy: materials of the 69th scientific session of the staff of the University "Vitebsk state medical University". Vitebsk, 2014. pp. 262263.

[17] Khramtsova T. G. The main techniques in teaching foreign languages T. G. Khramtsova // Problems of modern agricultural science: materials of the international correspondence scientific conference - Krasnoyarsk: Krasnoyarsk state agrarian university. - 2017. - p. 265-267.

[18] Volodina D. V., Yuryeva Yu. S. Possibilities of the electronic course application in teaching a foreign language in a technical university (on the basis of LMS Moodle) / / Russian Journal of Education and Psychology. 2017. No. 2-2. URL: https://cyberleninka.ru/article/n/vozmozhnosti-primeneniyaelektronnogo-kursa-pri-obuchenii-inostrannomu-yazyku-vtehnicheskom-vuze-na-baze-elektronnoy-platformy-moodle (accessed 21.11.2019).

[19] Mineeva O. A., Daricheva M. V. Organization of testing in LMS Moodle when teaching a foreign language / / Ped. Rev. 2016. No. 3 (13). URL: https://cyberleninka.ru/article/n/organizatsiya-testirovaniya-vsisteme-moodle-pri-obuchenii-inostrannomu-yazyku (accessed 21.11.2019).. 